1970. - Вып 9. - С. 90-109. 7. Протоколы заседаний Харьковского математического общества за 1885-1902 гг.// Сообщения Харьковского математического общества. 1886-1903 гг. 6. Цыкало А. Л. А. М. Ляпунов / А. Л. Цыкало - М. : Наука, 1988. - 246 с.

\title{
АНАЛІЗ ФІЛОСОФСЬКО-СВІТОГЛЯДНОЇ ТА КУЛЬТУРОЛОГІЧНОЇ СПЕЦИФІКИ ПРОЦЕСУ НАВЧАННЯ ФІЛОЛОГІЧНИХ ДИСЦИПЛІН У КОНТЕКСТІ РОЗВИТКУ РЕФЛЕКСИВНИХ УМІНЬ
}

Герасимова О. І. Аналіз філософсько-світоглядної та культурологічної специфіки процесу навчання філологічних дисциплін у контексті розвитку рефлексивних умінь.

У статті аналізується філософсько-світоглядна та культурологічна специфіка філологічних дисциплін; з'ясовується специфіка навчання філологічних дисциплін в умовах педагогічного університету, обгрунтовується необхідність реалізації єдності процесуального та змістового складників як у філологічному, так і в соціальнофілософському аспектах.

Ключові слова: рефлексія, рефлексивні уміння, філологічні дисципліни, самоосвіта, освітній процес.

Герасимова О. И. Анализ философско-мировоззренческой и культурологической специфики процесса обучения филологических дисциплин в контексте развития рефлексивных умений.

В статье анализируется философско-мировоззренческая и культурологическая специфика филологических дисциплин, определяется специфика обучения филологических дисциплин в условиях педагогического университета, обосновывается необходимость реализации единства процессуального и содержательного компонентов как в филологическом, так и в социально-философском аспектах.

Ключевые слова: рефлексия, рефлексивные умения, филологические дисциплины, самообразование, образовательный процесс.

Herasimova O. I. Analysis of philosophical and ideological and cultural specificity of learning process of philological disciplines in the context of development skills of reflection.

The article examines the philosophical and ideological and cultural specificity of philological disciplines, it turns out, the specifics of teaching philological disciplines under pedagogical university, identifies the need for the implementation of procedural and substantive unity as components in a philological and socio-philosophical aspects.

Key words: reflection, skills of reflection, philological discipline. self-education, educational process.

Нова парадигма педагогічної освіти розробляється на основі аксіом, що формуються на пріоритетах унікальності, амбівалентності особистості, опосередкованості iii розвитку. На тлі затвердження соціокультурних цінностей професійно-педагогічної підготовки студентів вищої школи на перший план висуваються завдання формування професійно-педагогічного світогляду студентів, фундаментом якого є варіативність, суб'єктність, особистий рефлексивний досвід. Цей вектор наукової та науково-практичної діяльності спрямовує зусилля викладачів на вироблення у студентів за період навчання у вищому педагогічному навчальному закладі певної системи якостей та властивостей, яка становитиме основу 
професіоналізму майбутнього фахівця. Однією з таких фундаментальних властивостей повинні стати рефлексивні уміння.

Узагальнення фундаментальних психолого-педагогічних досліджень переконує в тому, що оптимальним середовищем формування рефлексивних умінь студентів $\epsilon$ середовище вивчення філологічних дисциплін. Мають рацію ті дослідники, які тлумачать філологію і гуманітарні дисципліни загалом як прикладну психологію, підкреслюючи ту особливу функцію, яка втілюється не тільки і не скільки в опанування певної сукупності заздалегідь визначених знань та відповідних способів діяльності, скільки в засвоєнні «досвіду емоційно-ціннісного ставлення» (І. Лернер, В. Краєвський). У дисертаційних роботах О. Багдай, О. Гулеєвої, О. Раздорської, Ю. Сенько визначено, що середовище вивчення гуманітарних дисциплін $\epsilon$ найбільш сприятливим для формування не лише рефлексивних умінь, а й інших рефлексивних особистісних (рефлексивна позиція, рефлексивна спрямованість) та професійно-особистісних (рефлексивна готовність, рефлексивна компетентність, рефлексивна культура) новоутворень. Про розвиток рефлексивних механізмів та рефлексивних умінь особистості на тлі вивчення філологічних дисциплін йдеться в дослідженнях сучасних науковців, філологів - Т. Гундорової, Т. Денисової, Ю. Лотмана, Д. Наливайка, Г. Сиваченко, Е. Соловей та інших.

Meта статmі полягає у тому, щоб детально проаналізувати філософськосвітоглядну та культурологічну специфіку процесу навчання філологічних дисциплін у контексті розвитку рефлексивних умінь.

Реалізація організаційно-педагогічної умови активізації знаннєво-рефлексивного потенціалу певних навчальних дисциплін у спектрі нашої дисертаційної роботи вимагає детального аналізу філософсько-світоглядної та культурологічної специфіки процесу навчання філологічних дисциплін. Потреба цього аналізу підкріплена і зовнішніми чинниками: серед провідних тенденцій оновлення світового освітнього простору науковці (Н. Бордовська, 3. Курлянд, А. Реан, Р. Хмелюк) називають посилення гуманітарного складника у світовій освіті в цілому через уведення людино-орієнтованих навчальних дисциплін.

Нова гуманітарна ситуація в освітній галузі як в Україні, так і у світі характеризується, за висловом Л. Буєвої, двома провідними чинниками: невизначеністю та загальною й індивідуальною зорієнтованістю на майбутнє. Класична система взаємодії викладача та студента підлягає радикальному оновленню. Відмова від лише «знаннєвої» освіти, особливо в гуманітарній царині, відбувається у зв'язку з розумінням того фактору, що гуманітарні дисципліни не можуть викладатися і засвоюватися тими ж методами й прийомами, що й дисципліни природничо-наукові. Для наук про людину і суспільство головним є те, що вони вчать розуміти «інше», іншу людину, іншу культуру, іншу історію. В. Нургалєєв та Л. Барановська зауважують: «Людина, що вивчає гуманітарні дисципліни за допомогою неадекватних цим дисциплінам методів, які імітують методи природничі, буде людиною однобічною, недосконалою як особистість, невідповідною новій культурній ситуації» [3, с. 50]. Тож розкриття філософсько-світоглядної та культурологічної специфіки процесу навчання філологічних дисциплін допоможе віднайти оптимальні інструменти, механізми та засоби впливу на формування рефлексивних умінь сучасних студентів педагогічного університету.

Як відомо, завдання освіти полягає в тому, щоб надати можливість виявляти свій творчий потенціал, сприяти в реалізації особистих планів. Для цього необхідно навчитися розуміти самого себе, використовувати знання, що є продуктом власних роздумів, досвіду, самокритики, які побудовані не власне на інформативності, а більше 
на розумінні. Сприяє таким діям процес вивчення гуманітарних, зокрема філологічних дисциплін у вищій педагогічній школі.

Можливість гуманітаризації закладена у природі людського пізнання, оскільки навіть абстрактно-раціоналістичне знання, за твердженням М. Полані, створюється мистецтвом того, хто пізнає: «науковець робить власні висновки та обгрунтовує зроблене твердження так, як уважає правильним. На жодному етапі дослідження він не $\epsilon$ об'єктом керівництва 3 боку більш високого авторитету... пристрасність науковця регулятив пізнання, без якого воно поглинеться тривіальністю» [6, с. 125] (цитата за працею «The Foundations of freedom in Science»). Функція людського, «гуманітарного» пізнання - не лише пізнати, а й осмислити світ, надати йому певний сенс. Останнє передбачає не лише «суб' єктивованість», привласнення, а й свого роду доповнення, продовження знання у своєму вимірі. Саме цим питанням традиційна дидактика, займаючись проблемами моделювання пізнання в навчальному процесі, приділяла менше уваги, аніж питанням імітації логіки, інтелектуальних сторін пізнавального процесу тощо. Адже нині маємо чимало цікавих дидактичних концепцій і систем, які відбивають логіку пізнання, мислення, інтелектуальної діяльності (концепції розвивального, проблемного навчання, програмоване навчання та інші), i певну дидактичну порожнечу у полі трансформації інтерпретаційної гуманітаристки в дидактичну оболонку.

Безумовно, неприпустимими є «онтологізація ідеально чистих, істинних об'єктів науки, ототожнення наукових моделей 3 реальністю» 6, с. 125]. Наслідком абсолютизації науки $є$ перетворення іiі на певне «віровчення» (домінантна наскрізно інтернаціональна тенденція для минулого, XX століття) i, як результат цього, зниження гуманістичного потенціалу суспільної свідомості. Прикметним $\epsilon$ той факт, що ця небезпечна тенденція була розпізнана й 3 артикульована не лише філософами, культурологами, представниками гуманітаристики (С. Аверінцев, М. Мамардашвілі, Ф. де Соссюр, Е. Фромм, Й. Хейзінга, О. Шпенглер та інші), а й представниками світової природничо-наукової думки (С. Капіца, С. Курдюмов, Г. Малінецький та інші). Вислід небезпечної тенденції абсолютизації науки - зниження гуманістичного потенціалу суспільної свідомості. «Псевдонауковість суспільного буття тісно пов'язана 3 наукоподібністю навчання, 3 відсутністю продуманого співвіднесення його технічних і гуманітарних аспектів, - цілком слушно зауважує сучасний науковець В. Сєріков.Освіта, як і будь-яке людське діяння в умовах демократичного суспільства, звільнюється від анонімності, безликості. У таких умовах традиційний «план навчально-виховної роботи» перетворюється на програму самореалізації, спільного існування інтересів...» [5, с. 100]. Аналогічні судження висловлюють й інші науковці: «...реальний зміст процесу освіти не може зводитися лише до тих фрагментів науки, які закарбовані в навчальних програмах і підручниках» [4, с. 80],- пише Ю. Сенько і робить висновок: педагогічний прогрес безпосередньо залежить від гуманітарного феномену, повного розкриття потенціалу гуманітарних дисциплін.

Найвідоміші західноєвропейські та американські науковці й педагоги у різні часи висловлювали ідею про необхідність для будь-якої людини мати класичну гуманітарну освіту, складником якої була б освіта літературна, філологічна. Цю ідею у ХХ столітті було підтримано видатними письменниками. Зокрема, Й. Бродський, говорячи про політиків і керівників держав, наголошував: «Мені думається, що потенційних володарів наших доль варто було б опитувати, перш за все не про те, яким він уявляє курс іноземної політики, а про те, як він ставиться до Стендаля, Діккенса, Достоєвського. Хоч би вже за тим, що насущним хлібом літератури є сама людська розмаїтість та безчинство, вона, література, є надійною протиотрутою від усіляких - 
відомих і майбутніх - спроб тотального, масового підходу до розв'язання проблем людського існування» [2, с. 457]. Тож філологічні дисципліни в педагогічному університеті повинні посідати виняткове місце.

Специфіка навчання філологічних дисциплін в умовах педагогічного університету визначається необхідністю реалізації єдності процесуального та змістового складників як у власне філологічному, так і в соціально-філософському аспектах. Ця специфіка аналізується в наукових дослідженнях Н. Волошиної, Г. Клочека, В. Жирмунського, досвід науковців-літературознавців акумулюється в методичних працях О. Бандури, Е. Пасічника, Б. Степанишина, Л. Тимофєєва, оскільки проблему надання якісних філологічних знань неможливо розв'язати без синтезу теоретичних i методичних компонентів.

Нові перспективи забезпечення якості навчання філологічних дисциплін відкриваються на тлі використання досягнень герменевтики. Герменевтика у широкому сенсі - спільна назва для багатьох діяльностей: окрім власне філософського розуміння, існує нині герменевтика філологічна, педагогічна, природничо-наукова, історіографічна та ін. Г. Богін зазначає, що історично саме філологічна герменевтика посідає перше місце серед цих діяльностей. Предмет філологічної герменевтики певною мірою дотичний до власне індивідуальних рефлексій особистості - це розуміння і засвоєння ідеального, представленого в текстовій формі. В широкому сенсі текстом деякі дослідники називають будь-який вислід людської діяльності (від власне класичних текстів до творів живопису, архітектури, промислового дизайну): «з герменевтичної точки зору методологія читання та інтерпретації текстів вербальних надає підстави для побудови методик «прочитання» всіх інших текстів і квазітекстів» [1, с. 43]. Прикладом герменевтичного потрактування в сучасній популярній художній літературі може слугувати «прочитання» сюжету «Тайної вечері» героєм роману Д. Брауна.

Розуміння розглядається як одне 3 «інобуття» рефлексії- зв'язки між гносеологічним образом і наявним досвідом, причому цей зв'язок функціонує таким чином: образ «фарбується» наявним досвідом, а досвід стає предметом ставлення, що змінюється у такий спосіб. Рефлексія - друге (після чуттєвого) джерело досвіду, найважливіше утворення, як зазначалося в першому розділі нашої роботи. Саме це утворення дозволяє вдосконалювати всю душевну і духовну структуру особистості та людської спільноти загалом у їх онтологічних проявах. Розуміння - провідна риса рефлексії, яка виникає в момент фіксації (об’єктивації, перетворення) рефлексії. Висловлена рефлексія $\epsilon$ інтерпретацією. Саме інтерпретація та інтерпретаційні вміння як похідні від рефлексивних займають провідне місце в удосконаленні процесу навчання філологічних дисциплін.

У процесі здійснення цілеспрямованої роботи з розвитку рефлексивних умінь студентів варто зважати на той факт, що читання та сприйняття інформативних матеріалів підручника суттєво різниться від читання та сприйняття художніх творів. Під час вивчення творів мистецтва відбувається передусім естетичний і емоційний розвиток індивіда, у зв'язку з цим провідними будуть такі прийоми, як повільне, виразне читання, які розвивають образне мислення читача. Розвиток рефлексивних умінь відбувається через виявлення творчого характеру слова, яке викликало емоційний відгук.

Робота з науковими філологічними текстами вимагає реалізації деяких вихідних положень. По-перше, передбачається попередня підготовка студентів (ознайомлення 3 аналогічною літературою, наявність певних уявлень у філологічній царині та гуманітаристиці загалом), розуміння основної науково-філологічної термінології. Подруге, наявність уміння занурюватись у текст, зосереджувати свою увагу, докладати вольових зусиль. Саме в цьому плані виникають численні труднощі: деякі студенти, 
поволі накопичуючи досвід такої роботи, не можуть концентрувати та підтримувати на відповідному рівні свою увагу, у результаті- випускають з поля зору провідні ідеї, положення, гублять провідну думку, як підсумок - есе, наукова стаття, рецензія або інший науковий філологічний текст видаються їм складними та нецікавими. Тож розвиток рефлексивних умінь - конче потрібна робота, яка повинна розгортатися саме на тлі вивчення філологічних дисциплін.

\section{Література}

1. Богин Г. И. Филологическая герменевтика / Георгий Исаевич Богин - Калинин: КГУ, 1982. - 86 с. 2. Бродский И. А. Книга интервью / Иосиф Александрович Бродский. - [3-е изд., испр. и доп.]. - М. : Захаров, 2005. - 784 с. 3. Нургалеев В. Диалог культур как основа современной педагогической парадигмы / В. Нургалеев, Л. Барановская// Высшее образование в России. - 2004. - № 12. - С.48-51. 4. Сенько Ю. В. Гуманитарные основы педагогического образования: Курс лекций: [учеб. пособ. для студ. высш. пед. учеб. заведений] / Ю. В. Сенько. - М. : Изд. центр «Академия», 2000. - 240 с. 5. Сериков В. В. Личностный подход в образовании: концепции и технологии: [монографія]/ Владислав Владиславович Сериков.Волгоград: Перемена, 1994. - 152 с. 6. Polanyi М. The Foundations of freedom in Science / M. Polanyi // Physical Science and Human Values. - N.Y., 1969. - P. 125.

\section{ОСОБЛИВОСТІ ПРОФЕСІЙНОЇ ПІДГОТОВКИ ІНЖЕНЕРІВ У НІМЕЦЬКИХ ВНЗ У СИСТЕМІ ДУАЛЬНОЇ ОСВІТИ}

Гарасюта В. М. Особливості професійної підготовки інженерів у німецьких ВНЗ у системі дуальної освіти.

У статті висвітлюються основні питання організації навчання інженерів у німецьких ВНЗ у системі дуальної освіти. Розглянуто переваги професійної підготовки майбутніх фахівців у процесі дуального навчання. Подано вимоги до майбутніх інженерів 3 боку підприємств i навчальних закладів. Викладено можливості працевлаштування випускників.

Ключові слова: професійна освіта, дуальна освіта, професійна підготовка, інженер.

Гарасюта В. М. Особенности профессиональной подготовки инженеров в немецких вузах в системе дуального образования.

В статье освещаются основные вопросы организации обучения инженеров в немецких вузах в системе дуального образования. Рассмотрены преимущества профессиональной подготовки будущих специалистов в процессе дуального обучения. Представлены требования к будущим инженерам со стороны предприятий и учебных заведений. Изложены возможности трудоустройства выпускников.

Ключевые слова: профессиональное образование, дуальное образование, профессиональная подготовка, инженер.

Garasyuta V. M. Features of the professional training of engineers at German universities in the dual education system.

The article deals with the key questions of the organization of training engineers at German universities in the dual education system. The advantages of training future professionals in the process of dual training are considered. The requirements for future 